\title{
The Structure of Sweeper Tentacles in the Black Coral Antipathes fiordensis
}

\author{
WALTER M. GOLDBERG ${ }^{1}$, KEN R. GRANGE², GEORGE T. TAYLOR ${ }^{1}$, \\ AND ALICIA L. ZUNIGA' \\ ${ }^{1}$ Department of Biological Sciences, Florida International University, University Park, \\ Miami, Florida 33199 and ${ }^{2}$ Department of Scientific and Industrial Research, \\ Division of Water Sciences, Wellington, New Zealand
}

\begin{abstract}
Normal tentacles on polyps of the black coral Antipathes fiordensis are less than $2 \mathrm{~mm}$ long and display well-defined, wart-like structures, the centers of which are marked by both flagella and microvilli. Both of these microappendages are characteristic of spirocytes, the dominant type of cnidocyte in normal tentacles. Sweeper tentacles, up to $15 \mathrm{~mm}$ long, form in apparent response to an alcyonacean epibiont. The external surface of the sweeper tentacle lacks the well-defined, wart-like batteries of the normal tentacle, and exhibits a general reduction in the appearance of surface microappendages. Nonetheless, there is a greater number of cnidae per unit area. No spirocysts are found in these sweeper tentacles. Instead, the cnidom is composed entirely of microbasic b-mastigophores (MbMs). More than $99 \%$ of these are of a single type that are structurally different from the MbMs found as a minority of the cnidae in normal tentacles. Changes in sweeper tentacle cnidae are compared with those occurring in modified tentacles of other anthozoans.
\end{abstract}

\section{Introduction}

Aggressive behavior by anthozoan coelenterates is effected by a variety of specialized structures containing nematocysts (see review by Bigger, 1988). Extrusion of septal filaments (preferred to "mesenterial" filaments; see Bayer and Owre, 1968) onto a competitor is a common strategy among scleractinian corals (Lang, 1973; Glynn, 1974; Loya, 1976; Cope 1981; Bak et al., 1982; Logan, 1984), and has been described in a corallimorpharian as well (Chadwick, 1987). Some anemones pos-

Received 22 January 1990; accepted 16 May 1990 sess specialized marginal vesicles - the acrorhagi-that are used for this purpose (Francis, 1973; Ottaway, 1978; Bigger, 1980; Ayre, 1982; Sebens, 1984). A few anthozoans are capable of forming specialized tentacles during aggressive interaction. den Hartog (1977) described the formation of specialized bulbous tentacle tips in corallimorphs after contact with stony coral competitors. In other species, the entire tentacle structure can be modified under such conditions. Some acontiate anemones develop short, opaque, blunt-tipped "catch" tentacles (e.g., Williams, 1975), while some scleractinian corals can form elongated "sweeper" tentacles (Lewis and Price, 1975; Bak and Elgerschuizen, 1976; den Hartog, 1977; Richardson et al., 1979; Wellington, 1980; Chornesky, 1983). Sweeper tentacles have also been described in a few gorgonian corals (Sebens and Miles, 1989 and references therein). In all these cases, the transformation occurs within 4-9 weeks, when the normal or feeding tentacle converts to a sweeper or catch tentacle as the result of contact with other coelenterate species (Wellington, 1980; Bak et al., 1982; Bigger, 1982; Chornesky, 1983). Intraspecific competition (Purcell and Kitting, 1982; Kaplan, 1983; Hidaka and Yamazato, 1984; Hidaka, 1985; Fukui, 1986) and competition with non-coelenterates (Hidaka and Miyazaki, 1984) also appear to be associated with changes in tentacular morphology.

The induction of sweeper and catch tentacles is accompanied by changes in the relative proportions of nematocysts and spirocysts, as well as by shifts in the type of nematocyst (den Hartog, 1977; Purcell, 1977; Wellington, 1980; Watson and Mariscal, 1983a, b; Hidaka and Yamazato, 1984; Fukui, 1986; Hidaka et al., 1987). However, these earlier observations were made with optical or scanning electron microscopes and the intracap- 
sular details of cnidae before and after conversion to the sweeper tentacle were not compared. Thus, only changes between classes of nematocysts could be detected, while more subtle changes within-class were not. Similarly, though some of the external differences between tentacle types have been documented (den Hartog, 1977; Hidaka and Miyazaki, 1984; Fukui, 1986; Sebens and Miles, 1989), little attention has been given to histological and cytological distinctions. Watson and Mariscal (1983a, b) examined catch tentacles from this perspective, while Doumenc (1972) and Bigger (1982) documented the ultrastructural differences between acrorhagi and tentacles. We know of no corresponding work for sweeper tentacles.

Antipatharian corals are little known, largely due to their typical occurrence in deeper water. However, on the southwest coast of New Zealand's south island, large, virtually monotypic black coral populations occur in depths of 5-30 m (Grange et al., 1981; Grange, 1985), and are thereby accessible to study. The structure of the polyp, including the tentacle and gastrodermis, has been examined by Goldberg and Taylor $(1989 a$, b) who referred to this species as Antipathes aperta Totton. However, further work has resulted in its re-description as the endemic A. fiordensis Grange, 1990. We now report on the occurrence of sweeper tentacles in these animals, and compare their morphological and cellular structure with unmodified tentacles.

\section{Materials and Methods}

The site for this study was Doubtful Sound, Fiordland, New Zealand $\left(45^{\circ} 20.95^{\prime} \mathrm{S}, 167^{\circ} 02.83^{\prime} \mathrm{E}\right)$. Living material was photographed in situ at $10-20 \mathrm{~m}$ to document the incidence of sweeper tentacles. Color transparencies were examined microscopically to estimate tentacular size.

Branchlets with normal polyps and tentacles, as well as areas of the colony where sweeper tentacles had formed, were collected and immediately fixed for $4 \mathrm{~h}$ in a solution of $3 \%$ glutaraldehyde and $1 \%$ paraformaldehyde in seawater containing $0.1 \mathrm{M}$ cacodylate at $\mathrm{pH}$ 7.4. The fixed tissues were then transferred to cacodylate-buffered seawater and express-shipped to Miami for secondary fixation in osmium tetroxide, alcohol dehydration, and embedment in Spurr resin.

Sections of tentacle $1 \mu \mathrm{m}$ thick were normally stained for $30 \mathrm{~s}$ at $55^{\circ} \mathrm{C}$ with borax-buffered $0.05 \%$ Toluidine blue, but sweeper tentacles required much shorter staining times (see Results). A Philips EM 200 operated at $60 \mathrm{kV}$ was used for transmission electron microscopy; scanning electron microscope observations were made with an ISI Super 3A SEM, using material critical-point dried from liquid $\mathrm{CO}_{2}$. Proportional counts of cnidae types were made by examining randomly chosen $1 \mu \mathrm{m}$ sections taken from 8 normal and 8 sweeper tentacles until at least 1000 cnidae were counted.

\section{Results}

The appearance of the normal polyp of $A$. fiordensis is shown in Figure 1. Each polyp has six tentacles (five are shown) that surround the mouth and pharynx. The pharyngeal region also projects from the polyp as an oral cone (see Goldberg and Taylor, 1989a, for details). The living tentacles are $1.2 \pm 0.6 \mathrm{~mm}$ long and taper to a blunt tip. There is no distinct acrosphere. The tentacle surface is organized into a series of raised, wart-like batteries, with flagella projecting from their centers (Figs. 2, 3 ). The warts in the apical regions are flagellated, but are better defined proximally. Ciliary cones (stereocilia surrounding a longer central cilium) are scattered and are not a prominent feature of the tentacular epidermis. Spirocysts comprise $88.7 \%$ of the tentacular cnidae. Their capsules are clear and do not stain with Toluidine blue (Fig. 3 inset). The hirsute appearance of the wart center is largely a function of the mature spirocyte (Fig. 3 ), the apical end of which bears a circlet of microvilli and a single, acentrically placed flagellum $10 \mu \mathrm{m}$ or more in length (Goldberg and Taylor, 1989a).

Cells at the wart periphery and base tend to stain deeply with Toluidine blue. Part of this pattern is accounted for by the staining of the mucus cells, and part by the staining of nematocysts. Mucus cells stain a metachromatic pink, especially around the vesicles. The vesicles themselves develop a much lighter metachromasia. Most of the nematocysts stain a deep purple. The capsules average $2.5 \mu \mathrm{m}$ wide by $18.0 \mu \mathrm{m}$ long, and contain a triply pleated tubule in a poorly infiltrated, generally electron-opaque matrix (Fig. 3). The shaft is cylindrical, nearly the length of the capsule, and $0.5 \pm 0.2 \mu \mathrm{m}$ wide. It is approximately uniform in diameter, tapers toward the base as it meets the tubule, and ends apically in a distinctive cap. These characters are consistent with the description of microbasic b-mastigophores (MbMs) given by Mariscal (1974), and are the nematocysts referred to by Goldberg and Taylor (1989a) as type A MbMs. They comprise about $8.7 \%$ of the tentacular cnidae. A second type is larger (up to $35 \mu \mathrm{m}$ long and $10 \mu \mathrm{m}$ wide), and displays a weak orthochromasia with Toluidine blue. The matrix has a granular appearance in the electron microscope. Conversely, the shaft, and to some extent the tubule, are electron-opaque. The shaft is 1.8 $\pm 0.3 \mu \mathrm{m}$ wide and about a third the capsule length. Despite these distinctions, this second type falls into the same nematocyst category as those described above, referred to as type B MbMs by Goldberg and Taylor (1989a). These large, granular nematocysts comprise 

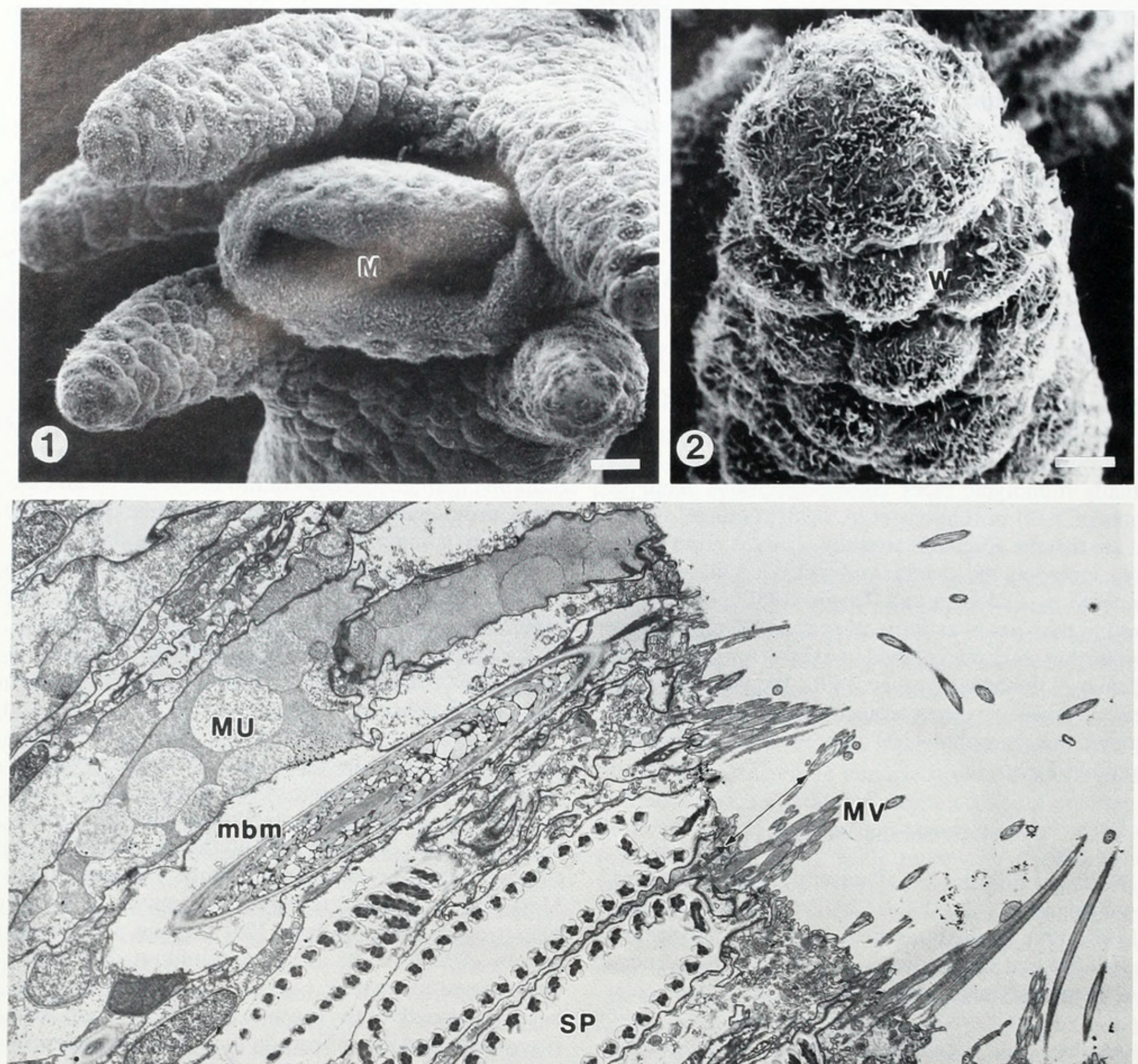

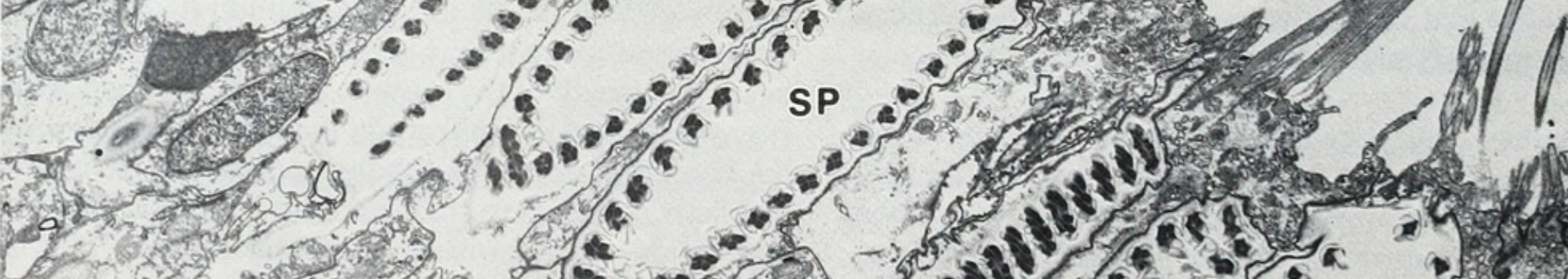
2.

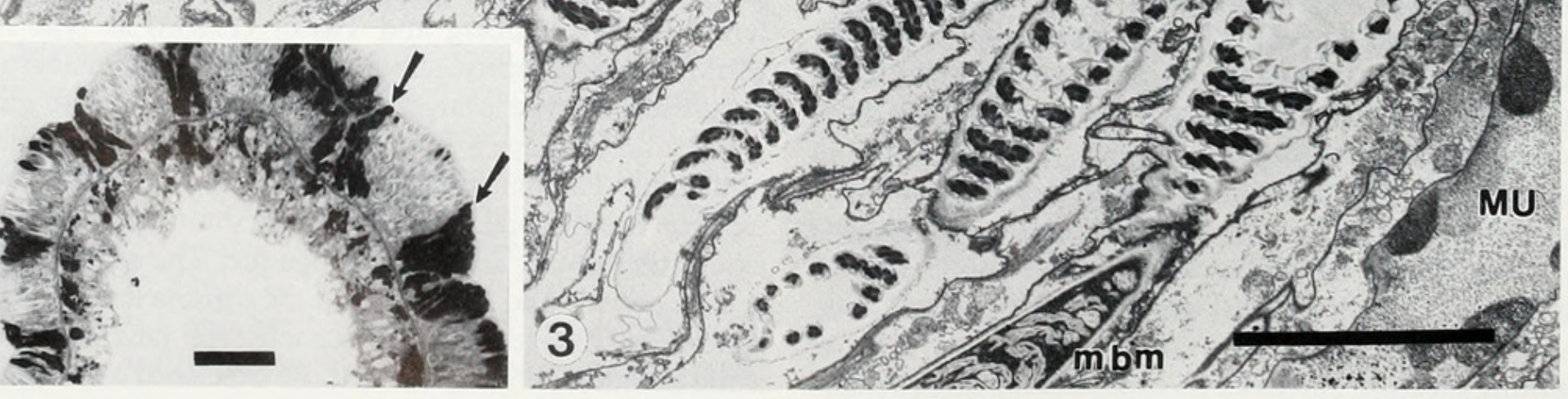

Figure 1. SEM preparation of Antipathes fiordensis polyp. Five of six tentacles are shown surrounding the mouth (M) in a central oral cone. Scale bar $=20 \mu \mathrm{m}$. Figure 2. Normal tentacle showing wart-like structures (W). The rim of the wart is composed of mucus cells; the depressed wart centers contain clusters 

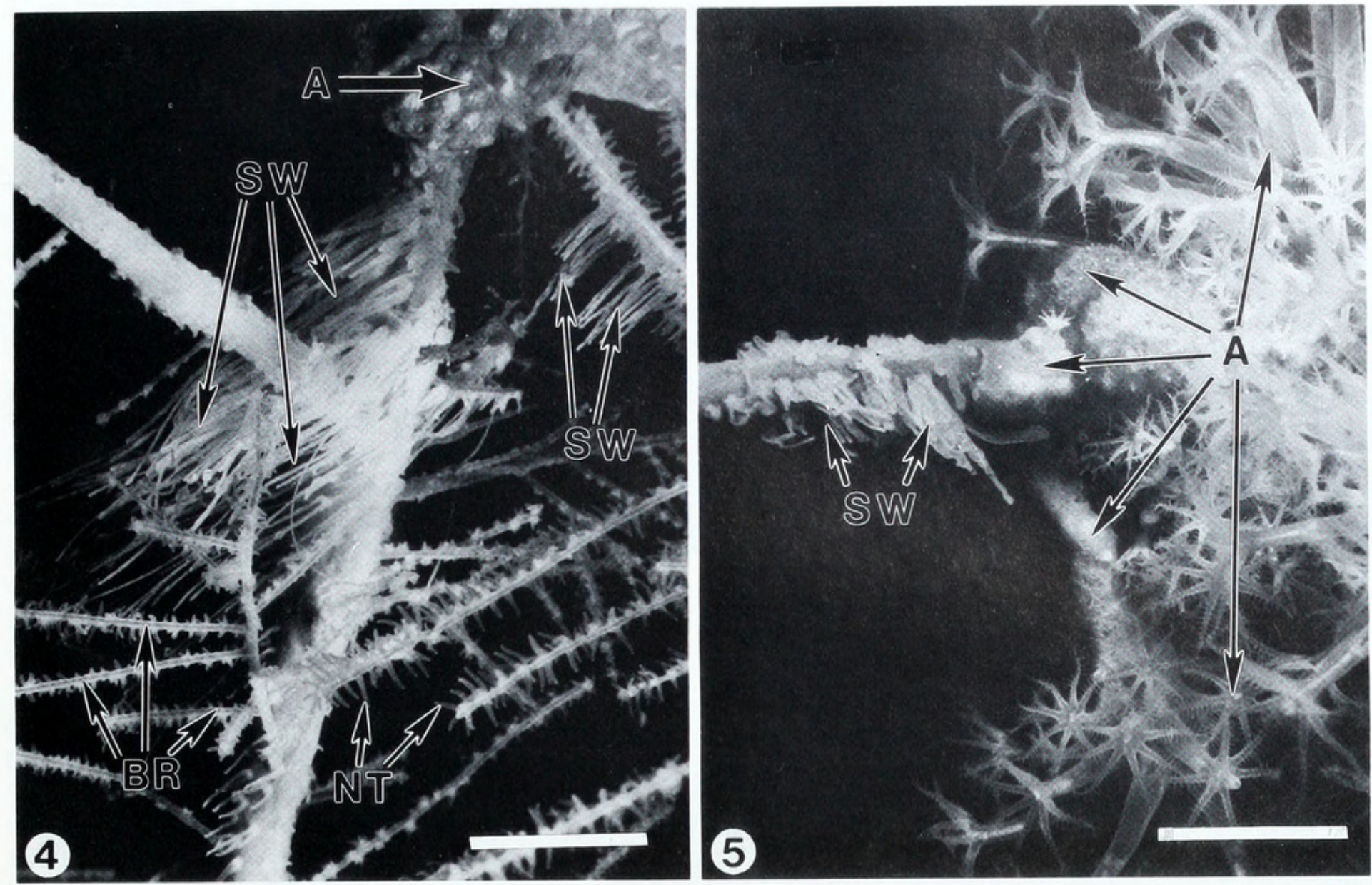

Figure 4. Sweeper tentacles (SW) adjacent to a contracted alcyonacean colony (A). Polyps with normal tentacles (NT) are located on branchlets (BR), while sweeper tentacles are usually confined to larger branches. Scale bar $=5 \mathrm{~mm}$. Figure 5. In situ photograph showing development of sweeper tentacles (SW) in association with expanded polyps of the alcyonacean coral Alcyonium aurantiacum (A). Note apparent gradation of tentacular length toward the epibiont. There are no normal $A$. fiordensis tentacles in this photograph. Scale bar $=5 \mathrm{~mm}$.

about $2.6 \%$ of the cnidae in the normal tentacle, but are the dominant cnida in the gastrodermis (Goldberg and Taylor, 1989b).

Sweeper tentacles in A. fiordensis are thread-like and extend up to $15 \mathrm{~mm}$ long (Fig. 4). A gradation of tentacle length may occur, either through contraction, distance from the competitor, or both, so that some tentacles may be as short as $2 \mathrm{~mm}$. We have examined all tentacle sizes histologically (see below), and have not found intermediates between normal and sweeper tentacles. There is no distinct acrosphere, in contrast to their formation or en- largement in other corals with sweeper tentacles (den Hartog, 1977; Chornesky and Williams, 1983; Hidaka and Miyazaki, 1984; Sebens and Miles, 1989), and their agonistic analogues in corallimorphs (den Hartog, 1977). A. fiordensis sweeper tentacles tend to form on thicker (older) branches, generally $4 \mathrm{~mm}$ or more in diameter and are especially common in the presence of the alcyonacean Alcyonium aurantiacum Quoy and Gaimard (Fig. 5). We have also noted them near red algae (Epymenia sp. and Lithothamnion sp.). However, in these instances we have not ruled out the presence of foreign

of flagella, representing the apical ends of cnidocytes. Scale bar $=20 \mu \mathrm{m}$. Figure 3. TEM preparation through a wart center perpendicular to the tentacular axis. Flagella and prominent microvilli (MV) are associated with the surface of mature spirocytes (SP). An arrow connects the flagellum and rootlet in this spirocyte. Two type A microbasic b-mastigophores ( $\mathrm{mbm}$ ) are shown. Upper left: a mature capsule with characteristic poorly infiltrated matrix. Lower right: an immature capsule with typical electron-opaque matrix. The raised edges of the wart are formed by mucus cells (MU). Scale bar $=5 \mu \mathrm{m}$. Inset: tentacular cross-section showing arrangement of stained mucus cells (arrows) surrounding unstained spirocyte clusters. Light microscopy; Scale bar $=20 \mu \mathrm{m}$. 

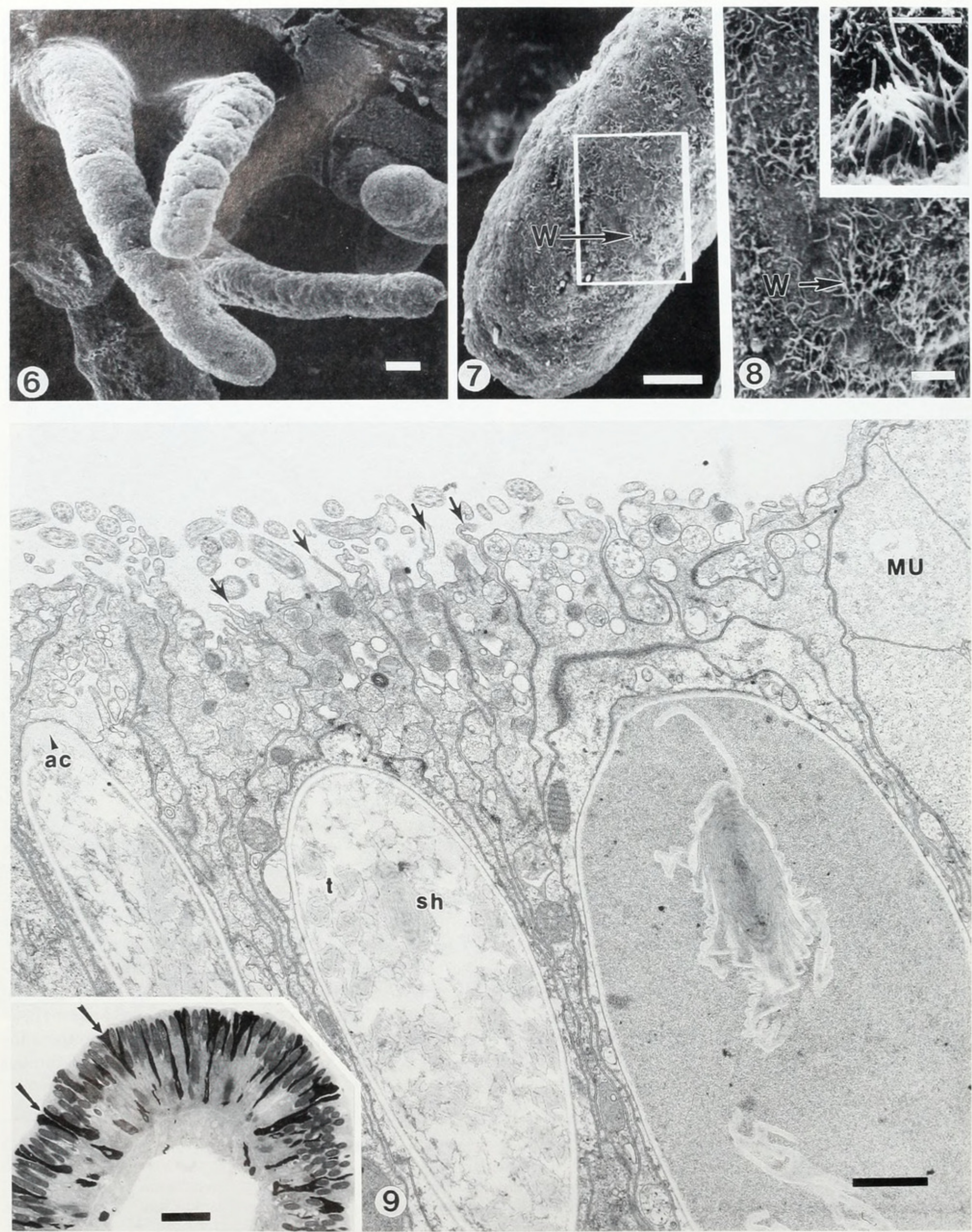

Figure 6. SEM preparation of sweeper tentacles. Note apparent absence of wart and microappendage structure. Surface cracks are artifacts of preparation. Scale bar $=50 \mu \mathrm{m}$. Figure 7. Higher magnification shows that surface ciliation occurs, but is greatly reduced. The center of a single wart (W) is indicated by 
coelenterate material, or the possibility that algal colonization was secondary.

Sweeper tentacles in these black corals are extremely fragile, especially after fixation and dehydration. Except for artifactual cracks, their surfaces appear smooth, without the wart-like structure of normal tentacles (Fig. 6). At higher magnification, low mound-like warts with hirsute projections at their centers can be distinguished (Figs. 7, 8 ). The cells in the wart center are primarily cnidocytes, the surfaces of which form short microvilli and have a central cilium usually $3 \mu \mathrm{m}$ or less in length (Fig. 9). The microvilli often form a collar-like arrangement at the tentacular surface (Fig. 8 inset), but ciliary cones, as such, apparently are absent (see Discussion).

Histologically, sweeper tentacles are completely different from their normal counterparts. The wart margins are still defined by mucus cells, but in sweeper tentacles these cells tend to be longer, narrower, and less numerous than those in normal tentacles (compare Figs. 3 inset and 9 inset). In addition, mucus cells stain more uniformly and produce a more intense pink metachromasia compared to their normal counterparts. More importantly, spirocysts are absent. All of the cnidae in the warts are nematocysts, and nearly all of them stain rapidly and deeply with Toluidine blue, giving the sweeper tentacle a comparatively uniform structure (Fig. 9 inset). Staining time must be held to less than $5 \mathrm{~s}$ at room temperature to avoid overstaining these cnidae. The capsules are $3.5 \pm 0.5 \mu \mathrm{m}$ wide and $22.5 \pm 2.5 \mu \mathrm{m}$ long. This is $40 \%$ wider and $25 \%$ longer than the dominant nematocyst found in normal tentacles. Warts generally contain 20-30 mature cnidae each, half or less of the 50-60 cnidae (mostly spirocysts) found in normal tentacles (Goldberg and Taylor, 1898a). Conversely, there is a greater number of warts per unit surface area in sweeper tentacles. In the boxed area of Figure 7, for example, 11 to 12 warts can be distinguished, whereas a comparable area from normal tentacle contains little more than two warts. Thus, sweeper tentacles contain approximately twice the number of cnidae per unit surface area.

Transmission electron microscopy shows that the structure of the shaft and capsule in the sweeper tentacle nematocysts are very similar to the type A MbMs described above from normal tentacle. However, differences in these cnidae become evident as they mature. The matrix becomes electron-lucent, tends to infiltrate poorly, and often shatters during sectioning. The shaft, matrix, and capsule wall usually lack adequate contrast (Fig. 9) even after overstaining. Occasionally, large nematocysts with a granular matrix can be found in or near final position (Fig. 9). These appear to be the same gastrodermal-type mastigophores that constitute $2.6 \%$ of the cnidae in the normal tentacle, but account for less than $1 \%$ of the sweeper tentacle nematocysts. These large cnidae also occur in the body wall epidermis of both normal and sweeper polyps. The latter appear to possess more of the gastrodermal cnidae than the sweeper tentacle, but proportionately no more than normal tentacle or body wall. Unlike normal polyps, however, the body wall is devoid of spirocysts. This condition indicates that the cnidae in the epidermis surrounding the sweeper tentacle are modified along with the tentacle itself.

\section{Discussion}

A few studies of sweeper or catch tentacle formation have included quantitative observations of the cnidae (Table I). In all but one of the specialized tentacles studied to date, spirocyst production is completely or almost completely suppressed in favor of nematocysts. In $\mathrm{Ga}$ laxea fascicularis there is a $50 \%$ reduction in the spirocyst population of the sweeper tentacle acrosphere (Hidaka and Yamazato, 1984). Because spirocysts function in adhesion during food capture (Mariscal, 1974; Mariscal et al., 1977), a change in favor of nematocysts is consistent with a change in tentacular function. However, a reduction in the development of surface microappendages in sweeper tentacle might not be predicted with the change from spirocysts to nematocysts. Mariscal et al. (1976) found microvilli, but no ciliary structures associated with spirocytes in several anthozoan species, and suggested that this may be an additional distinction between spirocytes and nematocytes. To the contrary, the normal tentacles of $A$. fiordensis are dominated by spiro-

the arrow. Scale bar $=20 \mu \mathrm{m}$. Figure 8. Triple magnification of boxed area in Figure 7 shows reduced wart-like structure. Scale bar $=5 \mu \mathrm{m}$. Inset: surface detail showing part of a single wart. Clustered microvilli suggest ciliary cones, but a prominent central cilium is not apparent. Scale bar $=5 \mu \mathrm{m}$. Figure 9. TEM preparation showing typical appearance of sweeper tentacle epidermis. The only cnidae are microbasic bmastigophores. The two at left are the type that constitute $>99 \%$ of the nematocysts, accompanied by an occasional large, gastrodermal-type microbasic b-mastigophore at right. The dominant cnida has an apical cap (ac), a triply pleated tubule (t), and distinct shaft ( $\mathrm{sh}$ ) in a poorly infiltrated, electron-lucent matrix. The rim of the sweeper tentacle wart is formed by mucus cells (MU). The surface of each cnidocyte is drawn into a short collar of microvilli (arrows) that surround a single cilium. Scale bar $=1 \mu \mathrm{m}$. Inset: mucus cells in sweeper tentacles tend to be elongated (arrows), and stain intensely with Toluidine blue, as do the dominant nematocysts, giving the sweeper wart structure a totally different appearance in the light microscope. Scale bar $=20 \mu \mathrm{m}$. 
TABLE I

Quantitative distribution of cnidae types in normal and modified tentacle

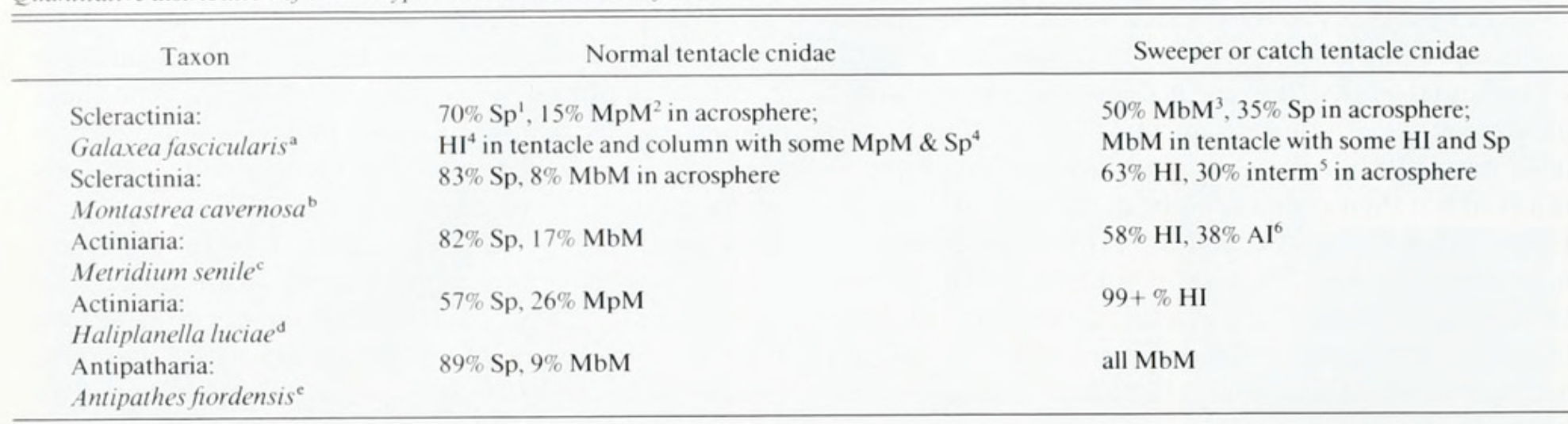

${ }^{a}$ Hidaka and Yamazato, 1984.

${ }^{\text {b }}$ den Hartog, 1977.

c Purcell, 1977.

${ }^{\mathrm{d}}$ Watson and Mariscal, 1983a

'This paper

${ }^{\prime}$ Spirocyst $=$ Sp.

${ }^{2}$ Microbasic p-mastigophore $=\mathrm{MpM}$

${ }^{3}$ Microbasic b-mastigophore $=\mathrm{MbM}$

${ }^{4}$ Holotrichous isorhiza $=\mathrm{HI}$.

${ }^{5}$ Cnidae intermediate in form between $\mathrm{HI}$ and $\mathrm{MbM}$

${ }^{6}$ Atrichous isorhiza $=\mathrm{AI}$.

cytes that not only possess well-developed microvilli, but are clearly ciliated (flagellated) as well (Goldberg and Taylor, 1989a). The distinct reduction in the hirsute appearance of its sweeper tentacles is therefore consistent with the absence of spirocytes. Further reduction in surface microappendage formation might result from a general decrease in epidermal microvilli. Because microvilli may serve as a reserve pool of membrane (Erickson and Trinkhaus, 1976), they might assist in the formation of elongated structures in coelenterates (Eppard et al., 1989) including sweeper tentacles. Similarly, the absence of typical ciliary cones may be due to the shortness of the central cilium in the MbMs. Therefore, the absence of these putative receptor structures ( $c f$. Mariscal, 1974) may be more apparent than real. Indeed, Hidaka and Miyazaki (1984) have suggested that ciliary cones may be typical of microbasic-b or p-mastigophores, as opposed to other nematocyst types. The presence of occasional ciliary cone structures in normal $A$. fiordensis tentacles may correspond to the lower relative abundance of these cnidae compared to sweeper tentacles.

The change in nematocyst type on conversion to sweeper tentacle appears to be inconsistent across taxa. Some species replace MpM (microbasic p-mastigophores) or HI (holotrichous isorhizas) in feeding tentacles with MbMs (microbasic b-mastigophores), whereas others replace MbM or MpMs with HIs, among others (Table I). In the case of $A$. fiordensis, the change in the nematocyst population involves differences in mean cap- sule size, appearance of the mature matrix, and staining characteristics. Other characters, especially the appearance of the shaft, suggest that the sweeper tentacle cnidae remain as MbMs. However, this designation is tentative due to the relatively small population of mature cnidae that remain undamaged after sectioning. Changes in the size, shape, and other details of nematocyst structure have been documented during the conversion to sweeper tentacles in other species (den Hartog, 1977; Hidaka et al., 1987), as well as between metagenetic and ontogenetic stages of the same species (Fautin, 1988, and references therein). Some of these distinctions may be a function of taxonomy. Hidaka et al. (1987) discuss the problems of classification when attempting to distinguish populations of MbMs, basitrichs, and holotrichous nematocysts. They agree with Schmidt (1974), who concluded that intergrades exist between MbMs and basitrichs, and refer to both as b-rhabdoids. The inconsistencies listed in Table I may be resolved by lumping morphological characters of the shaft and tubule, but this may not address important functional changes that could be represented by increased capsule size (Watson and Mariscal, 1983a; Hidaka and Yamazato, 1984; Hidaka et al., 1987; this paper) and changes in the physical properties of the nematocyst matrix (this paper) that accompany the conversion of normal to sweeper or catch tentacle.

Several authors have correlated the morphogenetic pattern of catch tentacle development with the forma- 
tion of its cnidae (Purcell, 1977; Watson and Mariscal, 1983a; Hidaka and Yamazato, 1984; Hidaka et al., 1987). In our study, sweeper tentacles irrespective of size, had already formed at the time of sampling. Thus, we have not had an opportunity to observe changes presumably occurring in the cnidom over time. Watson and Mariscal (1983b) showed that in Haliplanella luciae, catch tentacles not only exhibited a change in the type of cnidae, but displayed a maturational gradient in cnidae development as well. The catch tentacle base contained $96.3 \%$ cnidoblasts (cells with immature cnidae). Conversely, the catch tentacle tip contained mature cnidae almost exclusively. The opposite pattern was seen in feeding tentacles, where the gradient in maturity occurred cross-sectionally, i.e., cnidoblasts were distributed along the base of the epidermis, while mature cnidae were restricted to the outer epidermis. These opposing patterns were not present in the sweeper tentacles of $A$. fiordensis. In both the normal tentacle (Goldberg and Taylor, 1989a) and the sweeper tentacle, nematocyst development took place in a cross-sectional gradient, not a longitudinal one. Whether this is a general distinction between sweeper and catch tentacles, or simply a distinction between two species, remains unknown.

\section{Acknowledgments}

This work was supported in part by the NSF (OCE8613884 to W.M.G.) and in part by New Zealand DSIR (to K.R.G.). We thank Dick Singleton for assistance in the field. Charles Bigger and an anonymous reviewer made comments that improved the manuscript. Support of the U. S.-New Zealand Cooperative Science Program is also gratefully acknowledged.

\section{Literature Cited}

Ayre, D. J. 1982. Inter-genotype aggression in the solitary sea anemone Actinia tenebrosa. Mar. Biol. 68: 199-205.

Bak, R. P. M., and J. H. B. W. Elgerschuizen. 1976. Patterns of oilsediment rejection in corals. Mar. Biol. 37: 105-113.

Bak, R. P. M., R. M. Termaat, and R. Dekker. 1982. Complexity of coral interactions: influence of time, location of interaction and epifauna. Mar. Biol. 69: 215-222.

Bayer, F. M., and H. B. Owre. 1968. Pp. 25-123 in The Free-Living Lower Invertebrates. The Macmillan Co., New York.

Bigger, C. H. 1980. Interspecific and intraspecific acrorhagial aggressive behavior among sea anemones: a recognition of self and notself. Biol. Bull. 159: 117-134.

Bigger, C. H. 1982. The cellular basis of the aggressive acrorhagial response of sea anemones. J. Morphol. 173: 259-278.

Bigger, C. H. 1988. The role of nematocysts in anthozoan aggression. Pp. 295-308 in The Biology of Nematocysts, D. A. Hessinger and H. M. Lenhoff, eds. Academic Press, New York.

Chadwick, N. E. 1987. Interspecific aggressive behavior of the corallimorpharian Corynactis californica (Cnidaria: Anthozoa): Effects on sympatric corals and anemones. Biol. Bull. 173: 110-125.

Chornesky, E. A. 1983. Induced development of sweeper tentacles on the reef coral Agaricia agaricites: a response to direct competition. Biol. Bull. 165: 569-581

Chornesky, E. A., and S. L. Williams. 1983. Distribution of sweeper tentacles on Montastrea cavernosa. In The Ecology of Deep and Shallow Reefs, M. L. Reaka, ed. Symp. Ser. Undersea Res., N.O.A.A. Nat. Undersea Res. Prog. 1: 61-67.

Cope, M. 1981. Interspecific coral interactions in Hong Kong. Pp. 357-362 in Proc. Fourth Intl. Coral Reef Symp. 2. Manila, Philippines.

Doumenc, D. 1972. Adaptation morphologique de l'acrorhage chez Actinia equina L. Z. Zellforsch. Microsk. Anat. 129: 386-394.

Eppard, R. A., G. J. Highison, and R. W. Mead. 1989. Scanning electron microscopy of epithelial surfaces of the sea anemone Acontiophorum niveum (Phylum Cnidaria): Class Anthozoa. J. Morphol 200: 63-69.

Erickson, C. A., and J. P. Trinkhaus. 1976. Microvilli and blebs as sources of reserve surface membrane during cell spreading. Exp. Cell Res. 99: 375-384.

Fautin, D. G. 1988. Importance of nematocysts to actinian taxonomy. Pp. 487-500 in The Biology of Nematocysts, D. A. Hessinger and H. M. Lenhoff, eds. Academic Press, New York.

Francis, L. 1973. Intraspecific aggression and its effect on the distribution of Anthopleura elegantissima. Biol. Bull. 144: 73-92.

Fukui, Y. 1986. Catch tentacles in the sea anemone Haliplanella luciae: role as organs of social behavior. Mar. Biol. 91: 245-251

Glynn, P. W. 1974. Rolling stones among the Scleractinia: mobile corallith communities in the Gulf of Panama. Pp. 183-198 in Proc. Second Intl. Coral Reef Symp. 2. Great Barrier Reef Comm., Brisbane, Australia.

Goldberg, W. M., and G. T. Taylor. 1989a. Cellular structure and ultrastructure of the black coral Antipathes aperta: 1. Organization of the tentacular epidermis and nervous system. J. Morphol. 202: 239-254.

Goldberg, W. M., and G. T. Taylor. 1989b. Cellular structure and ultrastructure of the black coral Antipathes aperta: 2 . The gastrodermis and its collar cells. J. Morphol. 202: 255-270.

Grange, K. R. 1985. Distribution, standing crop, population structure and growth rates of black coral in the southern fiords of New Zealand. N. Z. J. Mar. Freshw. Res. 19: 467-475.

Grange, K. R. In press. Antipathes fiordensis, a new species of black coral (Coelenterata: Antipatharia) from New Zealand. N. Z. J. Zool.

Grange, K. R., R. J. Singleton, J. R. Richardson, P. J. Hill, and W. deL. Main. 1981. Shallow rock-wall biological associations of some southern fiords of New Zealand. N. Z. J. Zool. 8: 209-227.

den Hartog, J. C. 1977. The marginal tentacles of Rhodactis sanctithomae (Corallimorpharia) and the sweeper tentacles of Montastrea cavernosa (Scleractinia), their cnidom and possible function. Pp. 463-469 in Proc. Third Intl. Coral Reef Symp. 1, D. L. Taylor, ed. University of Miami Press, Coral Gables, FL.

Hidaka, M. 1985. Nematocyst discharge, histoincompatibility, and the formation of sweeper tentacles in the coral Galaxea fascicularis. Biol. Bull. 168: 350-358.

Hidaka, M., and I. Miyazaki. 1984. Nematocyst discharge and surface structure of the ordinary and sweeper tentacles of a scleractinian coral, Galaxea fascicularis. Galaxea 3: 119-130.

Hidaka, M., and K. Yamazato. 1984. Intraspecific interactions in a scleractinian coral, Galaxea fascicularis: induced formation of sweeper tentacles. Coral Reefs 3: 77-86.

Hidaka, M., I. Miyazaki, and K. Yamazato. 1987. Nematocysts characteristic of the sweeper tentacles of the coral Galaxea fascicularis (Linnaeus). Galaxea 6: 195-207.

Kaplan, S. A. 1983. Intrasexual aggression in Metridium senile. Biol. Bull. 165: 416-418.

Lang, J. C. 1973. Interspecific aggression by scleractinian reef corals. 
II. Why the race is not only to the swift. Bull. Mar. Sci. 23: 260279.

Lewis, J. B., and W.S. Price. 1975. Feeding mechanisms and feeding strategies of Atlantic reef corals. J. Zool. 176: 527-545.

Logan, A. 1984. Interspecific aggression in hermatypic corals from Bermuda. Coral Reefs 3: 131-138.

Loya, Y. 1976. The Red Sea coral Stylophora pistillata is an r-strategist. Nature 259: 478-480.

Mariscal, R. N. 1974. Nematocysts. Pp. 129-178 in Coral Biology: Reviews and New Perspectives, L. Muscatine and H. M. Lenhoff, eds. Academic Press, New York.

Mariscal, R. N., C. H. Bigger, and R. B. McLean. 1976. The form and function of cnidarian spirocysts 1 . Ultrastructure of the capsule exterior and relationship to the tentacle sensory surface. Cell Tiss. Res. 168: 465-474.

Mariscal, R. N., R. B. McLean, and C. Hand. 1977. The form and function of cnidarian spirocysts. 3. Ultrastructure of the thread and the function of spirocysts. Cell Tiss. Res. 178: 427-433.

Ottaway, J. R. 1978. Population ecology of the intertidal anemone Actinia tenebrosa. 1. Pedal locomotion and intraspecific aggression. Austr. J. Mar. Freshw. Res. 29: 787-802.

Purcell, J. C. 1977. Aggressive function and induced development of catch tentacles in the sea anemone Metridium senile (Coelenterata, Actiniaria). Biol. Bull. 153: 355-368.

Purcell, J. C., and C. L. Kitting. 1982. Intraspecific aggression and population distributions of the sea anemone Metridium senile. Biol. Bull. 162: 345-359.

Richardson, C. A., P. Dustan, and J. C. Lang. 1979. Maintenance of living space by sweeper tentacles of Montastrea cavernosa, a Caribbean reef coral. Mar. Biol. 55: 181-186.

Schmidt, H. 1974. On evolution in the Anthozoa. Pp. 533-600 in Proc. Second Intl. Coral Reef Symp. 1. Great Barrier Reef Comm., Brisbane, Australia.

Sebens, K. P. 1984. Agonistic behavior in the intertidal sea anemone Anthopleura xanthogrammica. Biol. Bull. 166: 457-472.

Sebens, K. P., and J.S. Miles. 1989. Sweeper tentacles in a gorgonian octocoral: morphological modifications for interference competition. Biol. Bull. 175: 378-387.

Watson, G. M., and R. N. Mariscal. 1983a. The development of a sea anemone tentacle specialized for aggression: morphogenesis and regression of the catch tentacle of Haliplanella luciae (Cnidaria, Anthozoa). Biol. Bull. 164: 506-517.

Watson, G. M., and R. N. Mariscal. 1983b. Comparative ultrastructure of catch tentacles and feeding tentacles in the sea anemone Haliplanella. Tissue Cell 15: 939-953.

Wellington, G. M. 1980. Reversal of digestive interactions between Pacific reef corals: mediation by sweeper tentacles. Oecologia 47: 340-343.

Williams, R. B. 1975. Catch tentacles in sea anemones: occurrence in Haliplanella luciae (Verrill) and a review of current knowledge. J. Nat. Hist. 9: 241-248. 


\section{$2 \mathrm{BHL}$ Biodiversity Heritage Library}

Goldberg, Walter M. et al. 1990. "The Structure of Sweeper Tentacles in the Black Coral Antipathes fiordensis." The Biological bulletin 179, 96-104. https://doi.org/10.2307/1541743.

View This Item Online: https://www.biodiversitylibrary.org/item/17377

DOI: https://doi.org/10.2307/1541743

Permalink: https://www.biodiversitylibrary.org/partpdf/24965

\section{Holding Institution}

MBLWHOI Library

\section{Sponsored by}

MBLWHOI Library

\section{Copyright \& Reuse}

Copyright Status: In copyright. Digitized with the permission of the rights holder.

License: http://creativecommons.org/licenses/by-nc-sa/3.0/

Rights: https://biodiversitylibrary.org/permissions

This document was created from content at the Biodiversity Heritage Library, the world's largest open access digital library for biodiversity literature and archives. Visit BHL at https://www.biodiversitylibrary.org. 